生省特難研究班の診断基準に従って特難と診断され, 初診から 1 年以上経過観察し得た症例のうち 5 回以上 純音聴力検率を施行し,明らかに聴力変動を認めた 105 症例を対象とした。研究方法は対象とした105例の経過 観察中に得られたオージオグラムから最良時と最覀時 の恥カレベルを観察し，その進行様式との関係につい て検討した。また，経過観察中旧 JIS と新 JIS が混在 している症例はすべて新 JISに換算した。また難聴自 覚時の年齢が20歳以下の症例31例を若年発症群とし, 21藏以上の症例74例を成人発症群とした。

結果及び考察 今回我々は特難の進行様式について 検討した，特難の変動幅は平均約 $25 \mathrm{~dB}$ となり突発性 難聴と比べると小さかった。また突発性難聴はその進 行が1回であるのに対し特難は進行し続ける点が異な る.この進行の持続が突発性難聴で聴力分布が 30 ・ $60 \mathrm{~dB}$ ではっきりしたが特難では，その分布が不明瞭
になった原因であると思われた。，老人性難恥も雨例性 に進行する感音性難聴だが, 特難より難聴の程度が軽 度で聴力型も高音漸傾型で特難とは異なる，また進行 の速度も特難の方が早い. 特難を若年発症群と成人発 症群に分けた時，出発点が $60 \mathrm{~dB}$ までは成人発症群の 方が悪化度は大きくなった。これは特難の病態に年䍅 変化が加わったのではないかと思われた。そてして出発 点が $60 \mathrm{~dB}$ 以上の時, 若年発症群は成人発症群上り悪 化度が大きくなった。この点からも若年発症群は $60 \mathrm{~dB}$ 以上の時，より箱重な経過観察が必要と思われ た。質問 八木昌人(東大)，高龄者の場含，生理 的な聴力低下と病的な低下の区別はどのようにして行 つているのか, 老人性難聴の場合は 1 年に何 $\mathrm{dB}$ 位聴 力低下がみられるのか 応答 難渎自覚時期, 急 速悪化などのアナムネ, および聴力レベル, 聴力型な よ゙から老人性難聴と鑑别した。

\title{
97 特発性両側性感音難聴における長期経過観察例の検討
}

\section{八木昌人 原田勇彦・山岨達也・菊地 茂（東大）}

今回私どもは 5 年以上経過観察が可能であった特発 性両側性感音難聴（以下特難と略記）の症例について, 聴力の変化を中心に検討を加えたのでここに報告す る。

東大病院耳鼻科にて 5 年以上経過観察が可能であっ た特難確実例12例対象とした。経過観察期間は 6 年 2 力月から 14 年 6 力月 (平均 108 力月) であった.

観察開始時と最終観察時のオージオグラムを比較す ると, 篗祭開始時には低音域に加之，中高音域も比 較的聴力の保た扎ている例が多いが，最終観察時には 全体として, 聴力闒值の上昇が目立つが, とくに, 中. 高音域での闇値の上昇が低音域に比して著しくなって いる，従って，特難が時間の経過とともに両側とも中・ 高音域を中心に高度蜼聴にいたることが示された。ま た，特難の進行様式を立木らの分類に従って検討する と，A， B， F， G 型のように経過は様々でも最終的 には両側同程度の難聴に至るものが12例中10例を占め た。次に急速進行の既往のある8例12耳についてさら に検討した。その結果，一側進行の症例では，のべ12 回の急速進行中10回が良聴耳にみられており，急速進 行は良聴耳に多く出現する傾向が推察された。最後に， 特難における聴力閾值の上昇速度について検討した。
測定周波数の算術平均少らの上昇速度は最も速いもの で $8 \mathrm{~dB} /$ 年，最も遅いもので $0.8 \mathrm{~dB} /$ 年であった。ま， 上昇速度を周波数別に検討すると, 低音域よりも中・ 高音域での上昇速度が速く, $125 \mathrm{~Hz}$ では $1.5 \mathrm{~dB} /$ 年, $250 \mathrm{~Hz}$ では約 $2.5 \mathrm{~dB} /$ 年であるのに対し，500から $4000 \mathrm{~Hz}$ では年平均 3.5 から $4 \mathrm{~dB}$ の進行がみとめられ t.

以上の結果から特難の進行については,個々の症例に 上り進行様式は様々であっても，長期的には両側同程 度の高度難聴に至る症例が多く，その聴力予後は極め て不良であることが推定された。質問 坂田英治 (埼玉医大)。このような例は，ワ氏反応陽性者をはじ め血族結婚子弟, 遺伝性家族性難聴, 薬物中毒などが みつかることが多いというのがわれわれの踄床経験で あるが，このような例はなかったか。応答 病歴 は詳細にとっており，1例に家族歴にて難聴者がみら れた。他の例については病歴上はとくに難聴の出現に 関係するようなものはみられなかった。質問 平 山方俊(横須賀市民)。聴力悪化速度は, 悪化前の㯖力 レベルで差がなったか 応答今回は, 難聴の程度 による進行速度の䔔いの有無については検討していな i.

\section{8. セロイジン切片法による内耳コルチ器内腔の}

\section{走査電顕による観察}

\author{
水田邦博・星野知之・森田浩文 酒井丈夫 (浜松医大)
}

目的 従来, コルチ器の内部, つまりコルチトンネ

ルやヌエル腔を走查電頻で観察するためには、コルチ 